\title{
Nicolae Saramandu \& Manuela Nevaci, Sinteze de dialectologie română, Editura Universitară, București, 2013, 232 p.
}

\author{
Dinu Moscal* \\ "Alexandru Philippide" Institute of Romanian Philology, Str. T. Codrescu 2, 700481 Iași, Romania
}

The authors, dialectologists with solid researches in South-Danubian Romanity, in the present volume offer a general outline of the history of Romanian dialectology and of Romanian dialects. The book's actual contribution consists in the description of the Romanian dialects spoken south of the Danube and, as indicated in the title, it resumes certain previously published individual studies.

In the first part of the volume (p. 17-99), unmarked as such in the book, the authors give a general account of the domain of dialectology, specifying the subject matter, methods and research directions of Romance and Romanian dialectology, also describing the atlases of Romanian dialects, which give a notable propaedeutic value to this section of the work. As the science of language variation, dialectology is presented beside its related linguistic sciences, also pointing out the essential characteristics of its subject matter (the territorial linguistic units), especially with reference to the folk variety, and the methods of delineation of those regions which conform with this quality compared to the transition areas between them. The authors describe the methods of dialectal linguistic data's collection, presentation and interpretation.

They also present the linguistic geography researches carried out within Romanian territory, beginning with the anticipatory activity of Hasdeu and continuing with Gustav Weigand, who made the first linguistic atlas of Romanian language, and with the description of the two subsequent series: Atlasul lingvistic român, elaborated by the Romanian Language Museum of Cluj, under the leadership of Sextil Puşcariu, and Noul atlas lingvistic român, series led by Emil Petrovici. It is also summarized (p. 49) the special case of Atlasului lingvistic moldovenesc (19681972).

South-Danubian dialectology is presented separ- ately (p. 49-65), despite the fact that the first results appear in the last two series presented above, with the specification that the results for the latter series were only partially made use of by the coordinator (Nicolae Saramandu). Unlike the commentary on Daco-Romanian dialect, in the case of the dialects spoken south of the Danube we encounter a critical analysis sustained by examples, which is naturally due to the fact that the authors are specialized in this field. Thus, comparisons are drawn between different dialects, subdialectal regions or contact areas with the neighbouring languages are identified and observations are made regarding the dialectal data's method of interpretation and record (cf. the interpretation of the form káțauă in the Megleno-Romanian dialect as "aromunische Tendenz", p. 58). The critical assessments made with respect to some aspects from papers on South-Danubian dialectology is corroborated by one of the authors' (Nicolae Saramandru) work which is currently in preparation but whose presentation (p. 61-65) induces high expectations for any reader interested in this domain.

The last two chapters of this first part (p. 6699) are dedicated to spatial linguistics illustrated in case of Romanian language by presenting the results obtained for 'godmother' ("woman who baptizes the child") and for 'clover' in Romance territory which are based on one of the authors' (Manuela Nevaci) earlier research. Some abbreviations are missing from the afferent section of the work's beginning. Discussing the issue of motivational maps and of the common mentality, the authors seek to clarify the linguistic sign's motivation. Although a distinction is made between internal motivation (i.e. between the signifier and the signified) and the motivation of the referent (p. 84-86), the discussion does not clarify the relation between the two entities of the linguistic sign and the referent between which there is another

*Email address: dinumoscal@yahoo.com. 
type of motivation. In addition, the redesignation in several Romance languages and in English of the grain's ear by terms with the meaning 'head' instead of the initial Indo-European terms with the meaning 'sharp' (p. 86, see also p. 98, where "transparent" and "motivated" are associated) is considered to be a "remotivation". Naturally, such oscillations do not decrease the least the value of the anthropologicalcultural explanations and information regarding the motivational analysis of examples from Romanian, Romance or Indo-European areas.

The second part of the volume (p. 100-213) is dedicated to Romanian dialects. It begins with a brief history of Romanian language and of its dialects (p. 100-107), followed by a synoptic description of Daco-Romanian dialect (p. 108-129) and by a more detailed presentation of the dialects spoken south of the Danube (p. 130-188) and it ends with placing Romanian dialects in the context of the Balkans ( $p$. 189-213).

The researches in Daco-Romanian dialects are chronologically presented, pointing out the two main directions regarding its subunits' delimitation: the first direction, initiated by $\mathrm{H}$. Tiktin, later adopted by M. Gaster and G. Weigand and ultimately concluded by E. Petrovici, also sustained by some additional contribution made by $\mathrm{R}$. Todoran, which led to the now classical delimitation of five subdialects and the second direction, intuited by M. Gaster and first demonstrated by A. Philippide, also sustained by S. Pușcariu and then by I. Gheție, based on the analysis of typical and atypical characteristics, and recommended by Em. Vasiliu, which distinguishes only two subdialectal areas (the "BanatoTranscarpathian" and the "Muntenian" subdivision respectively, as Philippide denotes them, or the southeastern and northwestern areas, as Gheție proposed). In their synthesis of Daco-Romanian dialect the authors adhere to this latter division (p. 116129).
The most substantial part of the volume is dedicated to South-Danubian dialects. The authors notice that, although a global research of these dialects is yet to be made, there exists a unity of research method and that the following step to be made in this field would be the study of these idioms (subdialects) and their comparative study thereof. In case of each subdialect the authors clearly identify the areas where it is spoken and the number of its speakers, also distinguishing its main peculiarities, especially in the case of the Aromanian dialect. A map of this account would have been fruitful though. The authors claim that South-Danubian dialects serve as a link to western Romanity (p. 135). It also should be noted that, according to historical tradition, Vlaşca, the name of a former county, is still considered to be a derivative of the vlah patronym, although things have never been really clarified. Regarding this issue we might take into account the study of Mircea Ciubotaru, entitled Revizuiri toponimice: Vlașca și Vlăsia, published in 2000.

All South-Danubian dialects are discussed on each linguistic level, pointing out the similarities and differences between them or, in some cases, between these and Daco-Romanian dialects. A real contribution is made with respect to Slavonic influence, especially Macedonian and Bulgarian, on Megleno-Romanian in term of the verbal aspect borrowing, a feature discussed so far only in case of IstroRomanian dialect (p. 149-153). On the lexical level the authors pay attention to Latin terminology which is not found in Daco-Romanian (p. 153-154) and to the Megleno-Romanian vocabulary which is more extensively analyzed (p. 155-165). In another chapter the authors discuss the Aromanian dialect spoken by immigrants in Dobrogea (p. 166188). The last chapter (p. 189-213) is dedicated to the relations between Romanian dialects and $\mathrm{Al}$ banian language and to the controversial issue of the Balkans' linguistic unity. 